\title{
ZSWIM4 Gene
}

National Cancer Institute

\section{Source}

National Cancer Institute. ZSWIM4 Gene. NCI Thesaurus. Code C150355.

This gene is involved in zinc binding. 